\title{
PHOSPHATE SOLUBILIZERS FROM THE RHIZOSPHERE OF Piper nigrum L. IN KARNATAKA, INDIA
}

\author{
Usha Seshachala ${ }^{1}$, and Padmavathi Tallapragada ${ }^{2 *}$
}

\begin{abstract}
Black pepper (Piper nigrum L.) is a climbing vine known for its pungent fruit used as a spice worldwide. The aim of this study was to evaluate the available $\mathrm{P}$ content in the native soils where pepper is grown as a crop plant. The native population of phosphate solubilising microbes (PSM) was studied from the rhizosphere of $P$. nigrum plants grown in the Western Ghats of Karnataka, India. A variety of phosphate solubilising bacteria and fungi were isolated from the rhizosphere soil samples. Phosphate solubilising capacity of different isolates was studied on Pikovskaya's medium. The isolates were tested for their phosphate solubilising capacity in vitro with three different phosphate sources, tricalcium phosphate (TCP), potassium dihydrogen phosphate (KHP), and rock phosphate (RP) in the concentrations $2.5,5.0$ and $7.5 \mathrm{~g} \mathrm{~L}^{-1}$. The three phosphate sources were solubilised by the isolates in varying proportions. The dominant PSM flora obtained from the samples included Bacillus and Aspergillus. The study showed that PSM utilised the three phosphate sources TCP, KHP, and RP with considerable variability. The phosphatase activity of the isolates showed that the predominant microorganisms were Bacillus subtilis $\left(5.33 \mathrm{U} \mathrm{mL}^{-1}\right)$ and Aspergillus $\left(11.5 \mathrm{U} \mathrm{mL}^{-1}\right)$. The predominant organisms were identified up to molecular level.
\end{abstract}

Key words: Aspergillus, Bacillus, phosphate solubilising microbes, 16s rDNA analysis.

$\mathrm{B}$ lack pepper (Piper nigrum L.) is used as a spicy condiment in foods throughout the world and has high economic value. It is cultivated in southern parts of India and in Indonesia. It is known for its pungent taste, aroma and flavour and is used in Ayurvedic, herbal and folklore medicines. In India it is cultivated in parts of Karnataka, Kerala, and Tamil Nadu.

Phosphorus is one of the major essential macronutrients for the biological growth and development of plants. Soils generally contain substantial reserves of total $\mathrm{P}$, though a major part of it remains relatively inert. Less than $10 \%$ of the total soil $\mathrm{P}$ is actually utilized and enters the plant-animal cycle. Phosphorus deficient plants are often severely stunted and all plant and animal life depends upon the synthesis of essential phosphate compounds by plants. Phosphate deficiency is wide spread and $\mathrm{P}$ fertilizers are universally required in the form of inorganic $\mathrm{P}$ fertilizers, only a small portion is actually utilized by the plants and the rest of it is converted into insoluble forms (Rodríguez and Fraga, 1999; Turan et al., 2007).

Phosphorus is an essential nutrient for plants, but is often not available due to its fixation in soil. Phosphate solubilising microorganisms (PSM) solubilise

${ }^{1}$ Dr. MGR University, Department of Microbiology, Maduravoyal, Chennai, 4000095 Tamil Nadu, India.

${ }^{2}$ Jain University, Department of Microbiology, Jayanagar Bangalore 560011, Karnataka, India.

"Corresponding author (vam2010tpraviju@gmail.com).

Received: 5 November 2011.

Accepted: 21 June 2012. insoluble phosphates and make it available to the plants (Bhattacharyya and Jain, 2000). Indian soils on an average contain much lesser phosphate that constitutes a portion of the plant dry weight. Even applied P combines with metal ions and PSM are required for its release (Bagyaraj and Varma, 1995). Phosphate solubilising microorganisms secrete organic acids and acid phosphates that act on insoluble phosphates. The principal mechanism for mineral phosphate solubilisation is the production of organic acids and acid phosphates play an important role in the mineralization of organic $\mathrm{P}$ in the soil. In addition, no significant amounts of organic acid production could be detected from phosphate solubilizer organisms. It is suggested that the release of $\mathrm{H}^{+}$ion to the outer surface in exchange for the cation uptake or constitute alternative ways for solubilisation of mineral phosphates (Schachtman et al., 1998).

The production of organic acids by phosphate solubilising bacteria (PSB) has been well documented. Gluconic acid seems to be the most frequent agent of mineral phosphate solubilisation. The PSM also produce amino acids, vitamins, and growth promoting substances (Ponmurugan and Gopi, 2006a). Phosphorus solubilising bacteria in general have been found effective in solubilising inorganic $\mathrm{P}$ in the soils. The organic acids produced include citric, glutamic, succinic, lactic, oxalic, malic, fumaric and tartaric acids as observed in several experiments. The action of organic acids has been attributed to its chelating properties. The phosphates thus solubilised are absorbed by the plants (Sundara et al., 2002). 
Phosphate solubilising microbes are a group of common soil organisms in the rhizosphere of several plants. Secretion of organic acids and phosphatases to solubilise insoluble phosphate to soluble forms are common in this group. Although several PSBs occur in the soil their numbers are not adequate to compete with other bacteria commonly established in the rhizosphere. Since the population of inorganic PSM in the soil is comparatively low, the number of PSM in the rhizospheric soil is more important than in the non-rhizospheric soil (Chailharn et al., 2008).

The availability of $\mathrm{P}$ for plant uptake is also determined by the amount of bioactivity in the soil. Phosphate solubilising microorganisms acting in unison with the plant roots are responsible for solubilising phosphatic minerals (Levyal and Janer, 2001). In natural systems PSM consist of a broad class of bacteria and fungi that interact in the soil, especially in the extreme micro environments found around the plant roots, the rhizosphere. While most PSM obtain a great deal of their energy needs from the plant root exudates, some derive their nutrient requirements directly from rock minerals (Taalab and Badr, 2007). These bacteria and fungi have a tremendous potential in being used as bio fertilizers and thus being currently promoted widely in agriculture. It has been reported that the highest numbers of PSM depends on the cultural activities and the different soil properties like physical and chemical properties and the content of organic matter and soil P (Yahya and Azawi, 1998).

The present study aims at isolation of phosphate solubilising microorganisms- and fungi from the rhizospheric soils of pepper in Karnataka, India. Our experiment focused at testing the solubility of various sources of inorganic phosphates by the PSM of pepper rhizosphere. The different phosphates tested included tricalcium phosphate, potassium dihydrogen phosphate, and rock phosphate at three different concentrations - 2.5, 5.0 and $7.5 \mathrm{~g} \mathrm{~L}^{-1}$. A comparative analysis of the solubility of the three phosphates by the PSM in the laboratory media was sought and the predominant PSM being identified up to molecular level.

\section{MATERIALS AND METHODS}

\section{Soil analysis}

Rhizospheric soil samples from four different pepper cultivating regions of Karnataka, India, were collected from six different regions in Murunadu $\left(12^{\circ} 18^{\prime} \mathrm{N}, 75^{\circ} 45^{\prime}\right.$ $\mathrm{E})$, and these soils were mixed together and triplicates were taken for further analysis. Similar procedure was followed from the other two different pepper plantations from Birur $\left(13^{\circ} 53^{\prime} \mathrm{N}, 75^{\circ} 58^{\prime} \mathrm{E}\right)$, and one home stead farm from Bangalore $\left(12^{\circ} 58^{\prime} \mathrm{N}, 77^{\circ} 48^{\prime} \mathrm{E}\right)$, co-cultivated with coconut (Cocos nucifera L.) trees, and these soils were analysed for their physico-chemical properties. The pepper plants were uprooted and the rhizospheric soil around roots was collected. Pepper plants selected were mature, 3-yr of age, and at fruiting stage for soil sampling to obtain variability in microorganisms. Soil samples were dried, crushed and passed through a $2 \mathrm{~mm}$ sieve to represent one composite sample (Sharma et al., 2007; Turan et al., 2007). The dried and homogenised soil was tested for their organic $\mathrm{C}$ and $\mathrm{P}$ content and $\mathrm{pH}$ in the concentration of $10 \mathrm{~g}$ in $100 \mathrm{~mL}$ of distilled water. Organic $\mathrm{C}$ was analysed using wet digestion method, $\mathrm{P}$ by using titrimetric method (Olsen and Sommers, 1982).

Murunadu is a hilly region of Karnataka with an annual rainfall of over 3000 to $3800 \mathrm{~mm}$ where pepper plants are grown in natural conditions on sloppy terrains, rich organic soils under the cover of tree plantation crops like coconut, coffee (Coffea arabica L.), areca (Areca catechu L.), tea (Camellia sinensis L. Kuntze), sesbania (Sesbania grandiflora [L.] Pers.) (Hamza et al., 2007). Birur is located in Malnad region of Karnataka, and receives normal average rainfall of $2725.5 \mathrm{~mm}$ and has red loamy soil. Bangalore soil is red loamy and receives an average rainfall of 150 to $200 \mathrm{~mm}$ and pepper plants are artificially irrigated.

\section{Isolation of phosphate solubilizers}

Phosphate solubilising fungi and bacteria were isolated from serial dilution technique. The soil was suspended in $9 \mathrm{~mL}$ of saline blank and serial dilutions of this stock were done to obtain dilutions of $10^{-6}$. Each dilution was pour plated on nutrient agar and Pikovskaya's medium (PK medium) simultaneously (Chen et al., 2002). Plates were incubated at $28-30{ }^{\circ} \mathrm{C}$ for 3-4 $\mathrm{d}$ for bacterial growth and 5-7 $\mathrm{d}$ for fungal growth. Pure cultures were identified on the basis of their morphological and cultural characteristics (Pikovskaya, 1948; Seshadri and Ignacimuthu, 2002).

The colonies surrounded with halo zones around it were picked and transferred thrice by streak plate method on to new Pikovskaya's medium to obtain pure cultures.

\section{Detection of phosphate solubilisation efficiency}

The isolates were spot inoculated on Pikovskaya's medium for detection of their phosphate solubilising capacity for three different phosphates tricalcium phosphate (TCP), potassium dihydrogen phosphate (KHP) and American rock phosphate $(\mathrm{RP})$ and incubated at $28{ }^{\circ} \mathrm{C}$ for 3 and $7 \mathrm{~d}$ for bacteria and fungi respectively. The halo zones around the colonies were measured in $\mathrm{mm}$ and the solubilising efficiency was calculated according to the formula (Abou El Yazeid et al., 2007):

$\mathrm{PSE}=($ diameter of zone/diameter of colony $) \times 100$. Phosphate solubilisation on Pikovskaya's solid medium was examined by growing the different isolates on PK media substituted with TCP, KHP, or RP. The solubilisation ability of different isolates for the three different phosphates was noted at three different concentrations -TCP, KHP and RP, used in different concentrations of 2.5, 5.0, and $7.5 \mathrm{~g} \mathrm{~L}^{-1}$ (Seshadri and Ignacimuthu, 2002; 
Ponmurugan and Gopi, 2006a; Nopparat et al., 2007). The phosphatase activity of the isolates was detected by using p-nitrophenol as substrate by colorimetric estimation (Ponmurugan and Gopi, 2006b).

\section{Identification of PSM}

Pure cultures were used for the identification of isolated organisms. The isolates sub cultured on the slants were identified morphologically and culturally using staining and cultural characteristics. Identification of the bacterial culture to its nearest species, 16s rDNA sequence data was obtained using genomic DNA. The $1.4 \mathrm{~kb}$ rDNA was amplified with the help of high fidelity (polymerase chain reaction) PCR polymerase. The PCR product thus obtained was sequenced bi directionally with the aid of forward, reverse and internal primers. A sample of $1 \mu \mathrm{L}$ of genomic DNA was taken and was amplified with $400 \mathrm{ng}$ of $16 \mathrm{~s}$ forward primer with the sequence of 5'-AGAGTRTGATCMTYGCTWAC-3' and $400 \mathrm{ng}$ of reverse primer reading 5'-CGYTAMCTTWTTACGRCT-3' and Taq polymerase enzyme (Sundara et al., 2002). The sequence data obtained was aligned and analysed to its nearest neighbours (Weisburg et al., 1991; Espinosa-Victoria et al., 2009).

The phylogenetic tree was built using System Software Aligner and the distance matrix was generated using the Jukes-Counter corrected distance model. The distance matrix was generated only with alignment model positions and the alignment inserts were ignored. The minimum position for alignment comparisons was 200 bases. The phylogenetic tree was constructed with an alphabet size of 4 and length size 1000 (Bruno et al., 2000). The fungal identification was carried out using the genomic DNA extracted from the pure culture. The internal transcribed spacer (ITS) region of the rDNA was amplified with the help of universal primers ITS $4 \& 5$ and then sequenced. The editing of the crude sequence was done using the manual mode and it was aligned with the reference sequence obtained from National Center for Biotechnology Information (NCBI) database (Rodríguez et al., 2006).

\section{Statistical analysis and experimental design}

All the investigations were conducted in triplicates. Viable count and primary isolation was done in triplicate. The phosphate solubilisation was conducted in Petri dishes in triplicate on PK media with a single organism inoculated in the centre as a point and from each replicate; three readings of the zone of inhibition were recorded in millimetres. Results were presented as the mean zone of inhibition for each organism. The phosphatase assay was carried out in Erlenmeyer flasks independently in triplicates, each flask containing $100 \mathrm{~mL}$ of the broth medium. Data were subjected to ANOVA with significance of \pm 0.5 . Most efficient phosphate solubilising bacteria and fungi were identified up to molecular level.

\section{RESULTS}

The soil analysis result shows a variable phosphate content in all soil samples (Table 1). The physicochemical analysis of the soil samples indicated low P content in correlation with the acidity of the soils in case of Murunadu and Birur soil samples, whereas Bangalore showed a higher $\mathrm{pH}$ and a lower P content. The first three soil samples tested showed a low $\mathrm{pH}$ ranging from 5.4 to 6.0 and showed the presence of high organic C content varying between 4.1-6.8\%. The rhizospheric soil samples collected from Murnadu, Birur, and Bangalore districts of Karnataka, India, range in the texture from black soil, clayey, to red loamy soil in Bangalore region. The soils being mainly fertilised with organic compost and fish meal (Birur) showed the presence of high organic $\mathrm{C}$ content but extremely low in phosphates (3-4 $\left.\mathrm{kg} \mathrm{ac}^{-1}\right)$. Pepper plants in these areas are co-cultivated with several species of tree plantation crops like coconut, coffee, areca, tea, and sesbania. It has been reported that these hilly regions where pepper cultivation is extensive, have a sloppy terrain resulting in soil losing its nutrients and being low in phosphates (Hamza et al., 2007).

\section{Phosphate solubilising microorganisms (PSM)}

Rhizospheric soils of pepper have yielded the presence of several bacterial and fungal forms that were capable of phosphate solubilisation in form of TCP, KHP and RP (Table 2) used in different concentrations of 2.5, 5.0 and $7.5 \mathrm{~g} \mathrm{~L}^{-1}$. The primary isolation of PSM on Pikovskaya's medium using soil dilution method indicated the presence of several species of bacteria - Bacillus, Arthrobacter, Pseudomonas, Streptomyces, Actinomycetes, and Nocardia. Thereafter the isolated bacteria were supplied

Table 1. Soil properties of rhizospheric soil samples of Piper nigrum in India.

\begin{tabular}{|c|c|c|c|c|c|c|}
\hline $\begin{array}{l}\text { Sample } \\
\mathrm{N}^{\circ}\end{array}$ & $\begin{array}{l}\text { Geographical location } \\
\text { from collected }\end{array}$ & $\begin{array}{l}\text { Soil } \\
\text { type }\end{array}$ & $\begin{array}{l}\text { Soil } \\
\text { pH }\end{array}$ & $\begin{array}{l}\text { Organic } \\
\text { carbon }\end{array}$ & $\begin{array}{c}\text { Phosphate } \\
\text { content }\end{array}$ & $\begin{array}{c}\text { Available } \\
\text { potash }\end{array}$ \\
\hline & & & & $\%$ & - & - \\
\hline 1 & $\begin{array}{l}\text { Murunadu, Karnataka, } \\
12^{\circ} 18^{\prime} \mathrm{N}, 75^{\circ} 45^{\prime} \mathrm{E}\end{array}$ & Black clayey soft & 5.4 & 1.4 & 7.4 & 291 \\
\hline \multirow[t]{2}{*}{2} & Birur, Karnataka & & & & & \\
\hline & $\begin{array}{l}13^{\circ} 53^{\prime} \mathrm{N}, 75^{\circ} 58^{\prime} \mathrm{E} \\
\text { Birur, Karnataka }\end{array}$ & Red loamy soil & 5.7 & 4.1 & 7.4 & 617 \\
\hline 3 & $\begin{array}{l}13^{\circ} 53^{\prime} \mathrm{N}, 75^{\circ} 58^{\prime} \mathrm{E} \\
\text { Bangalore, Karnataka }\end{array}$ & Red loamy soil & 6.0 & 3.7 & 9.9 & 948 \\
\hline 4 & $12^{\circ} 58^{\prime} \mathrm{N}, 77^{\circ} 48^{\prime} \mathrm{E}$ & Red soil & 8.0 & 6.8 & 7.4 & 1007 \\
\hline
\end{tabular}


Table 2. Phosphate solubilising bacteria from Piper nigrum rhizosphere on Pikovskaya's medium with $5.0 \mathrm{~g} \mathrm{~L}^{-1}$ of tricalcium phosphate (TCP).

\begin{tabular}{|c|c|c|c|c|}
\hline $\begin{array}{l}\text { Sample } \\
\mathrm{N}^{\circ} \\
\end{array}$ & $\begin{array}{c}\text { Soil } \\
\text { sample }\end{array}$ & $\begin{array}{c}\text { Organisms } \\
\text { isolated }\end{array}$ & $\begin{array}{l}\text { Colony count } \\
\left(\text { In cfu g }{ }^{-1}\right)\end{array}$ & $\begin{array}{l}\text { Zone } \\
(\mathrm{mm})\end{array}$ \\
\hline \multirow[t]{3}{*}{1} & \multirow[t]{3}{*}{ Murunadu, Karnataka } & Bacillus spp. & $3 \times 10^{4}$ & 8 \\
\hline & & Arthrobacter & $3 \times 10^{4}$ & 0 \\
\hline & & Pseudomonas & $6 \times 10^{3}$ & 2 \\
\hline \multirow[t]{2}{*}{2} & \multirow[t]{2}{*}{ Birur 1, Karnataka } & Streptomyces & $5 \times 10^{4}$ & 5 \\
\hline & & Bacillus subtilis & $3 \times 10^{3}$ & 28 \\
\hline 3 & Birur 2, Karnataka & Actinomycetes & $4 \times 10^{3}$ & 10 \\
\hline \multirow[t]{3}{*}{4} & \multirow[t]{3}{*}{ Bangalore, Karnataka } & Bacillus spp., & $4 \times 10^{3}$ & 10 \\
\hline & & Actinomycetes & $2 \times 10^{4}$ & 5 \\
\hline & & Nocardia & $6 \times 10^{6}$ & 6 \\
\hline
\end{tabular}

with different phosphates TCP, KHP and RP (Table 2) at 2.5, 5.0 and $7.5 \mathrm{~g} \mathrm{~L}^{-1}$. Amongst the isolated bacteria the most predominant forms with maximum phosphate solubilisation capacity were various species of Bacillus. The predominant PSF included Aspergillus species. The results (Table 2) indicated greater numbers of these forms in the rhizospheric zone showing maximum clearance of phosphate on Pikovskaya's medium. The maximum zone of clearance was shown by B. subtilis $(28 \mathrm{~mm})$ and a minimum zone was given by the Actinomycetes isolate. Solubilisation efficiency of TCP, KHP and RP by different bacteria and fungi are indicated in Figures 1 and 2. TCP was found to be solubilised greatest by Bacillus subtilis followed by Bacillus species str 2 at a concentration of 2.5 $\mathrm{g} \mathrm{L}^{-1}$, but at $5.0 \mathrm{~g} \mathrm{~L}^{-1}$ it was seen that B. subtilis showed the maximum zone. Though the optimum concentration for solubilisation of KHP by the bacterial isolates was at $7.5 \mathrm{~g} \mathrm{~L}^{-1}$, the solubilisation of TCP and KHP was much reduced at $2.5 \mathrm{~g} \mathrm{~L}^{-1}$. The solubilisation of $\mathrm{RP}$ was rather too negligible or not solubilised by the bacterial isolates.

Among the different species of Aspergillus isolated, A. niger showed optimum zone with TCP and KHP, but reduced activity for RP. The other isolates showed variations in their phosphate solubilisation efficiency at the concentrations of 2.5 and 5.0 as well as at $7.5 \mathrm{~g} \mathrm{~L}^{-1}$ of different phosphates (Table 3).

The dominant phosphate solubilizers were identified as B. subtilis $(86 \mathrm{~mm})$ among bacteria and A. niger $(26.3$

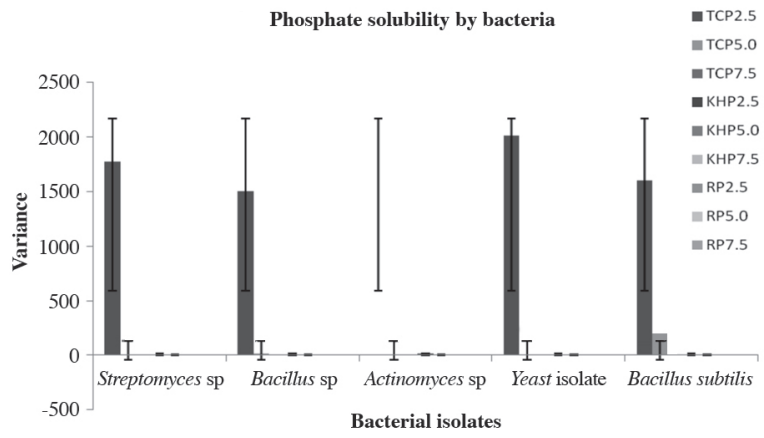

Legend denotes concentrations of phosphates used in $\mathrm{g} \mathrm{L}^{-1}$ in Pikovskaya's medium in the experiment.

Figure 1. ANOVA graph for zone of clearance for tricalcium phosphate (TCP) and potassium dihydrogen phosphate (KHP) with sd bar for bacterial isolates.

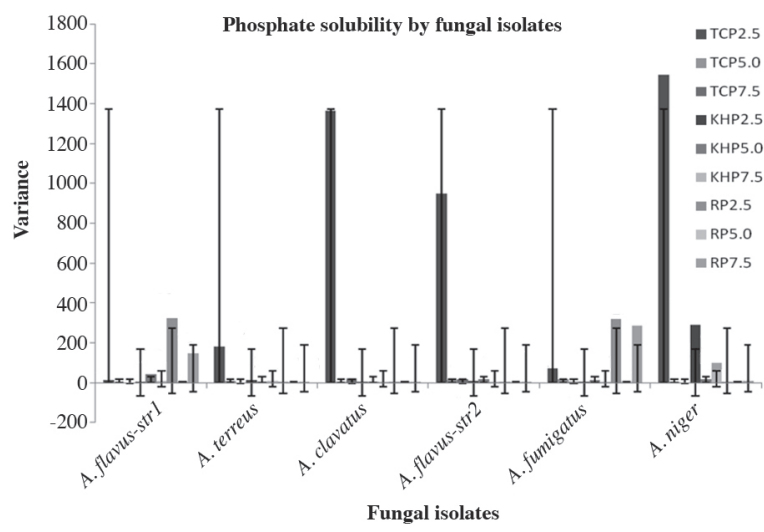

Legend denotes concentrations of phosphates used in $\mathrm{g} \mathrm{L}^{-1}$ in Pikovskaya's medium in the experiment.

Figure 2. ANOVA graph for zone of clearance for tricalcium phosphate (TCP), potassium dihydrogen phosphate (KHP), and rock phosphate (RP) by fungi isolates.

Table 3. Phosphate solubilising fungi from Piper nigrum rhizosphere on Pikovskaya's medium with $5.0 \mathrm{~g} \mathrm{~L}^{-1}$ of tricalcium phosphate (TCP).

\begin{tabular}{|c|c|c|c|c|}
\hline $\begin{array}{l}\text { Sample } \\
\mathrm{N}^{\circ}\end{array}$ & $\begin{array}{c}\text { Soil } \\
\text { sample }\end{array}$ & $\begin{array}{c}\text { Organisms } \\
\text { isolated }\end{array}$ & $\begin{array}{l}\text { Colony count } \\
\left(\text { In } \mathrm{cfu} \mathrm{g}^{-1}\right)\end{array}$ & $\begin{array}{l}\text { Zone } \\
(\mathrm{mm})\end{array}$ \\
\hline \multirow[t]{2}{*}{1} & Murunadu, Karnataka & Aspergillus niger & $4 \times 10^{5}$ & 6 \\
\hline & & Aspergillus sps 1 & $2 \times 10^{6}$ & 10 \\
\hline 2 & Birur 1, Karnataka & Aspergillus sps 2 & $4 \times 10^{4}$ & 5 \\
\hline 3 & Birur 2, Karnataka & A.terreus & $4 \times 10^{6}$ & 4 \\
\hline 4 & Bangalore, Karnataka & A.flavus & $5 \times 10^{4}$ & 7 \\
\hline
\end{tabular}

$\mathrm{mm}$ ) among fungal isolates. Both strains were able to solubilise TCP, KHP, and RP efficiently at an optimum concentration of $5.0 \mathrm{~g} \mathrm{~L}^{-1}$. The phosphatase activity of the isolates showed that the predominant isolates $B$. subtilis and $A$. niger had the maximum activity for phosphate solubilisation (Figure 3).

\section{Fungal identification}

The six strains of Aspergillus used in the study of phosphate solubilisation were identified based on morphological and cultural features (Ponmurugan and Gopi, 2006a). They were identified as A. flavus, A. terreus, A. clavatus, A. flavus str. 2, A. fumigatus and A. niger.

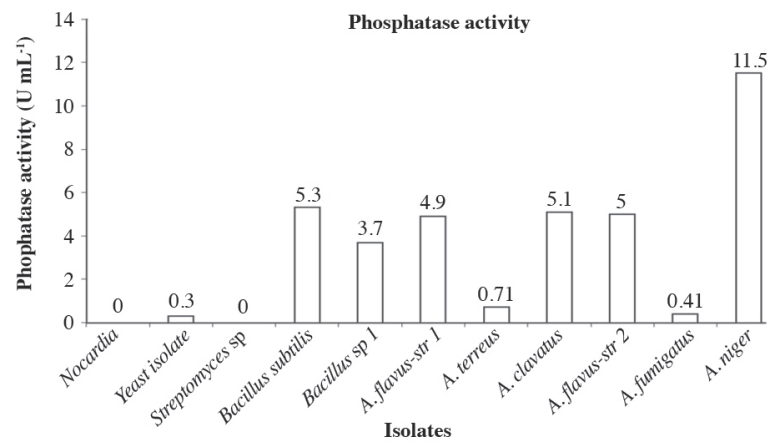

Values denote the phosphate activity of the isolates.

Figure 3. Phosphatase activity of isolates from rhizosphere of Piper nigrum. 
The strain of A.Niger, which showed a maximum zone of clearance with different phosphates, was identified using genomic DNA extract from the pure culture. It possessed 100\% ITS sequence similarity with seven Aspergillus species: Aspergillus vadensis Samson R.P. de Vries, Frisvad (2005), A. tubingensis (Mosseray) Kozak (1934), A. foetidus Thom \& Raper (1945), A. costaricaensis Samson \& Frisvad (2004), A. niger var. niger Tiegh. (1867), A. awamori Nakaz. (1915), and A. niger var. phoenicis (Corda) Al-Musallam (1980).

Table 4 gives the alignment sequence data of A. niger which showed $100 \%$ similarity with $A$. niger var. niger Tiegh. (1867) and A. awamori Nakaz. (1915).

Amongst the different bacterial forms solubilising phosphates, the predominant form Bacillus was identified to its nearest species based on 16s rDNA sequence data (Table 5).

Table 4. The aligned sequence data obtained for Aspergillus niger ( 554 bp).

GCGGGTCCTTTGGGCCCAACCTCCCATCCGTGTCTATTATACCCTGTT GCTTCGGCGGGCCCGCCGCTTGTCGGCCGCCGGGGGGGCGCCTTTG CCCCCCGGGCCCGTGCCCGCCGGAGACCCCAACACGAACACTGTCT GAAAGCGTGCGTCTGAGTTGATTGAATGCAATCAGTTAAAACTTTCA ACAATGGATCTCTTGGTTCCGGCATCGATGAAGAACGCAGCGAAATG CGATAACTAATGTGAATTGCAGAATTCAGTGAATCATCGAGTCTTTGA ACGCACATTGCGCCCCCTGGTATTCCGGGGGGCATGCCTGTCCGAGC GTCATTGCTGCCCTCAAGCCCGGCTTGTGTGTTGGGTCGCCGTCCCC CTCTCCGGGGGGACGGGCCCGAAAGGCAGCGGCGGCACCGCGTCC GATCCTCGAGCGTATGGGGCTTTGTCACATGCTCTGTAGGATTGGCC GGCGCCTGCCGACGTTTTCCAACCATTTTTTCCAGGTTGACCTCGGA TCAGGTAGGGATACCCGCTGAACTTAAGCATATCAATA

Table 5. The aligned sequence data obtained for Bacillus subtilis subsp. subtilis.

$>$ GP

GGGGAAGTGGTGGCTTGCTCATGATGTTAGCGGCGGACGGGTGAGTAAC ACGTGGGTAACCTGCCTGTAAGACTGGGATAACTCCGGGAAACCGGGGC TAATACCGGATGGTTGTTTGAACCGCATGGTTCAGACATAAAAGGTGGCT TCGGCTACCACTTACAGATGGACCCGCGGCGCATTAGCTAGTTGGTGAGG TAACGGCTCACCAAGGCAACGATGCGTAGCCGACCTGAGAGGGTGATCG GCCACACTGGGACTGAGACACGGCCCAGACTCCTACGGGAGGCAGCAG TAGGGAATCTTCCGCAATGGACGAAAGTCTGACGGAGCAACGCCGCGTG AGTGATGAAGGTTTTCGGATCGTAAAGCTCTGTTGTTAGGGAAGAACAA GTGCCGTTCAAATAGGGCGGCACCTTGACGGTACCTAACCAGAAAGCCA CGGCTAACTACGTGCCAGCAGCCGCGGTAATACGTAGGTGGCAAGCGTT GTCCGGAATTATTGGGCGTAAAGGGCTCGCAGGCGGTTTCTTAAGTCTGA TGTGAAAGCCCCCGGCTCAACCGGGGAGGGTCATTGGAAACTGGGGAA CTTGAGTGCAGAAGAGGAGAGTGGAATTCCACGTGTAGCGGTGAAATGC GTAGAGATGTGGAGGAACACCAGTGGCGAAGGCGACTCTCTGGTCTGTA ACTGACGCTGAGGAGCGAAAGCGTGGGGAGCGAACAGGATTAGATACCC TGGTAGTCCACGCCGTAAACGATGAGTGCTAAGTGTTAGGGGGTTTCCGC CCCTTAGTGCTGCAGCTAACGCATTAAGCACTCCGCCTGGGGAGTACGGT CGCAAGACTGAAACTCAAAGGAATTGACGGGGGCCCGCACAAGCGGTG GAGCATGTGGTTTAATTCGAAGCAACGCGAAGAACCTTACCAGGTCTTG ACATCCTCTGACAATCCTAGAGATAGGACGTCCCCTTCGGGGGCAGAGTG ACAGGTGGTGCATGGTTGTGTCAGCTCGTGTCGTGAGATGTTGGGTTAAG TCCCGCAACGAGCGCAACCCTTGATCTTAGTTGCCAGCATTCAGTTGGGC ACTCTAAGGTGACTGCCGGTGACAAACCGGAGGAAGGTGGGGATGACGT CAAATCATCATGCCCCTTATGACCTGGGCTACACACGTGCTACAATGGGCA GAACAAAGGGCAGCGAAACCGCGAGGTTAAGCCAATCCCACAAATCTGT TCTCAGTTCGGATCGCAGTCTGCAACTCGACTGCGTGAAAGCTGGAATCG CTAATAAACGCGGAACAGCATATGCGCGTCTTTT.

\section{Bacterial identification}

Analysis of $\sim 1.4 \mathrm{~kb}$ rDNA fragment of the bacterium was done using high $\sim$ fidelity PCR polymerase amplification. Sequence data showed the identification of the bacterium B. subtilis; RB14; FJ263381. The closest neighbour homologue was Bacillus amyloliquefaciens; 7-70; fj378040.

The alignment view and distance matrix (Table 5) for the organism $B$. subtilis showed 0.961 s.ab score with B. subtilis; 3EC2A10 of NCBI Acc. $N^{\circ}$ EU304917 (Hamaki et al., 2005; Fankem et al., 2006; Tallapragada and Seshachala, 2012). Phylogenetic tree was generated using Juke's Cantor distance model (Figure 4) (Bruno et al., 2000; Espinosa-Victoria et al., 2009).

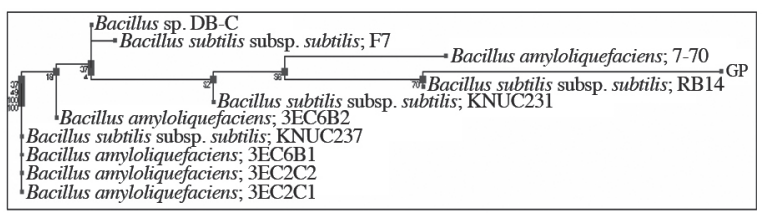

Figure 4. Phylogenetic tree for Bacillus subtilis subsp. subtilis.

\section{DISCUSSION}

Results are supported by similar observations made in a study which clearly indicates high efficiency of phosphate solubilisation by Bacillus species and Aspergillus species (Rajankar et al., 2007). Accordingly it was found that fungi have been more efficient in solubilising phosphates than bacterial isolates. The intracellular phosphatase activity of these organisms showed a higher value too, A. niger being the most efficient with an activity of 11.5 $\mathrm{Um} \mathrm{L}^{-1}$ and giving the greatest amongst bacteria with an activity of $5.33 \mathrm{Um} \mathrm{L}^{-1}$ at $\mathrm{pH} 10$.

The dominant phosphate solubilizers were identified using molecular techniques up to species level. The $16 \mathrm{~s}$ rDNA sequencing resulted in the identification of the predominant phosphate solubilizers as $B$. subtilis and $A$. niger.

The present study indicates that soils with higher organic content showed a greater number and variety of rhizospheric soil bacteria and fungi capable of phosphate solubilisation. The greater numbers of PSB have been shown in Birur 1 and Birur 2 soil samples with optimum levels of organic content and lower $\mathrm{pH}$. As reported by other workers (Malakooti and Nafisi, 1995) the organic content of the soil positively influenced the presence of phosphate solubilizers in the rhizospheric soils yielding greater numbers of these organisms than in the non rhizospheric soils. The $\mathrm{pH}$ of the soil also plays an important role in phosphate uptake and has been shown that the best $\mathrm{pH}$ for P uptake is 6.5 (Venkateshwarulu et al., 1984). A great proportion of $\mathrm{P}$ in chemical fertilizers becomes unavailable to the plants after its application. This is due to the strong bonds between $\mathrm{P}$ with $\mathrm{Ca}$ and 
$\mathrm{Mg}$ in the alkaline $\mathrm{pH}$ and the same bonds with $\mathrm{Fe}$ and $\mathrm{Al}$ in the acidic soils. The mobility of this element is very slow in the soil and cannot respond to the rapid uptake by plants (Arpana et al., 2002). Recent studies have showed that based on eco-physiological characteristics, phosphate solubilising bacteria and fungi have better efficiency to provide with available $\mathrm{P}$ in poor and unfertilized soils (Mehrvarz and Chaichi, 2008).

Solubilisation efficiency of TCP, KHP, and RP by both bacterial and fungal isolates was high as shown in the results obtained. Many of the bacterial organisms were able to solubilise TCP and KHP effectively. Rock phosphate was solubilised more rapidly and efficiently by both Bacillus and Aspergillus species (Abou El-Yazied et al., 2007). High phosphate solubilising capacity of $B$. subtilis has been reported in studies conducted in several experiments (Fankem et al., 2006).

The use of RPas fertilizer in the recent years has received significant interest since they are natural, inexpensive, and easily available fertilizers. However its solubilisation occurs less rapidly in acidic soils (Ouahmane et al., 2000; Caracava et al., 2004). Physical and chemical treatments like thermal alteration and partial acidification increase $\mathrm{P}$ availability from RP are expensive. A much cheaper and convenient alternative is reclamation through the use of phosphatic biofertilizers containing PSM. In this aspect, studies have been conducted with RP solubilising activity of Aspergillus species (Kang et al., 2008).

Aspergillus niger has shown the maximum efficiency amongst the fungal isolates with a zone of $26.1 \mathrm{~mm}$ at 2.5 $\mathrm{g} \mathrm{L}^{-1}$ TCP. It has been reported that $A$. niger is capable of producing some organic acids which are known to solubilise relatively insoluble phosphates (Singh and Amberger, 1998) and synergistic effects of the acids have been proposed by several workers (Parks et al., 1990). These attributes of the fungal strain of A. niger are an important mechanism for solubilisation of relatively insoluble P (Goenadi et al., 2000). The study of A. niger has been carried along with other Aspergillus species as an efficient RP and fluorapatite solubilizer, where lowering of $\mathrm{pH}$ of soil was found to be associated with solubilisation process (Cereziine et al., 1988; Caracava et al., 2004; Kang et al., 2008).

In the present study it has been observed that the PSM play an important role in reclamation of $\mathrm{P}$ to the soil. All rhizospheric samples exhibited high numbers of phosphate solubilising microbes which indicates good phosphate solubilisation activity in the soils. The high capacity of $A$. niger (26.1 $\mathrm{mm}$ at $\left.2.5 \mathrm{~g} \mathrm{~L}^{-1} \mathrm{TCP}\right)$ and $B$. subtilis $(86 \mathrm{~mm}$ at $2.5 \mathrm{~g} \mathrm{~L}^{-1} \mathrm{TCP}$ ) as PSM promises their use as potential phosphatic biofertilizers. Hence there is need to develop these strains as phosphatic fertilizer which can be helpful in reducing the use of inorganic chemical fertilizers and increase the fertility of the soils. Black pepper being a highly valuable plantation crop is used not only in India but also in West Asia, Arabic countries, Greece, North
West Africa, and Europe as part of their exotic cuisines. Increasing the soil fertility by application of phosphatic fertilizers is an efficient eco-friendly way of obtaining higher yields of the crop.

\section{CONCLUSIONS}

The present study indicates the presence of phosphate solubilising organisms in the rhizospheric soils of pepper plants in the growing regions of Karnataka, India. The study clearly shows the ability of these rhizobacteria and fungi in the solubilisation of inorganic phosphates and the role played by these organisms in enhancing the fertility of the soil. The phosphate solubilising ability of Bacillus subtilis subtilis and Aspergillus niger can be exploited further by using them as $\mathrm{P}$ fertilizers in the field of agriculture and crop plantation after further field studies done to support these findings.

Solubilizadores de fosfatos desde la rizósfera de Piper nigrum L. en Karnataka, India. La pimienta negra (Piper nigrum L.) es una planta trepadora conocida por su fruto utilizado como especia en todo el mundo. El objetivo de este estudio fue evaluar el contenido de P disponible en los suelos nativos donde se cultiva. La población nativa de microbios solubilizantes de fosfato (PSM) fue estudiada en la rizósfera de plantas de P. nigrum cultivadas en los Ghats occidentales de Karnataka, India. Una variedad de hongos y bacterias solubilizantes de fosfato fueron aislados de muestras de suelo de la rizósfera. La capacidad solubilizadora de fosfato de diferentes aislamientos fue estudiada en medio de Pikovskaya. Los aislados fueron probados para su capacidad de solubilizar in vitro tres fuentes diferentes de fosfato, fosfato tricálcico (TCP), potasio dihidrógeno fosfato (KHP) y roca fosfórica (RP) en las concentraciones de 2,5; 5,0 y 7,5 $\mathrm{g} \mathrm{L}^{-1}$. Las tres fuentes de fosfatos fueron solubilizadas por los aislados en proporciones variables. La flora dominante de PSM obtenida de las muestras incluyó especies de Bacillus y Aspergillus. El estudio mostró que PSM utilizaron el fosfato de las tres fuentes, TCP, KHP y RP, con considerable variabilidad. La actividad de fosfatasa de los aislamientos mostró que los microorganismos predominantes eran Bacillus subtilis $\left(5,33 \mathrm{U} \mathrm{mL}^{-1}\right)$ y Aspergillus $\left(11,5 \mathrm{U} \mathrm{mL}^{-1}\right)$. Los organismos predominantes fueron identificados hasta el nivel molecular.

Palabras clave: Aspergillus, Bacillus, microbios solubilizantes de fosfato, análisis $16 \mathrm{~s}$ rADN.

\section{LITERATURE CITED}

Abou El-Yazeid, A., H.E. Abou-Aly, M.A. Mady, and S.A.M Moussa. 2007. Enhancing growth, productivity and quality of squash plants using phosphate dissolving microorganisms (Biophos-phor $\left.{ }^{\circledR}\right)$ combined with boron foliar spray. Research Journal of Agricultural and Biological Sciences 3:274-286. 
Arpana, N., S.D. Kumar, and T.N. Prasad. 2002. Effect of seed inoculation, fertility and irrigation on uptake of major nutrients and soil fertility status after harvest of late sown lentil. Journal of Applied Biology 12:23-26.

Bagyaraj,D.J., and A. Varma. 1995. Mineral phosphate solubilization: Agronomic implications, mechanisms and molecular genetics. Advances in Microbiological Ecology 14:119-142.

Bhattacharyya, P., and R.K. Jain. 2000. Phosphorus solubilizing biofertilizers in the whirlpool of rock phosphate- challenges and opportunities. Fertilizer News 45:45-52.

Bruno, W.J., D.S. Nicholas, and L.H. Aaron. 2000. Weighted neighbor joining: A likelihood - based approach to distancebased phylogeny reconstruction. Molecular Biological Evolution 17:189-197.

Caracava, F., M.M. Alguacil, R. Azcón, G. Díaz, and A. Roldán. 2004. Comparing the effectiveness of mycorrhizal inoculation and amendment with sugar beet, rock phosphate and Aspergillus niger to enhance field performance of the leguminous shrub Dorycnium pentaphyllum L. Applied Soil Ecology 25:169-180.

Cereziine, P.C., E. Nahas, and D.A. Banzatto. 1988. Soluble phosphate accumulation by Aspergillus niger from fluorapatite. Applied Microbiology Biotechnology 29:501-505.

Chailharn, M., S. Chunhaleuchanon, A. Kozo, and S. Lumyong. 2008. Screening of rhizobacteria for their plant growth promoting activities. KMITL Science and Technology Journal 8:18-23.

Chen, X., J. Tang, Z. Fang, and S. Hu. 2002. Phosphate solubilizing microbes in rhizosphere soils of 19 weeds in south-eastern China. Journal of Zhejiang University Science 3:355-361.

Espinosa-Victoria, D., L. López-Reyes, and A. De La Cruz-Benítez. 2009. Use of 16s RNA gene for characterization of phosphatesolubilizing bacteria associated with corn. Revista de Fitotecnia Mexico 32:31-37.

Fankem, H., D. Nwaga, A. Deubel, L. Dieng, W. Merbach, and F.X. Etoa. 2006. Occurrence and functioning of phosphate solubilizing microorganisms from oil palm tree (Elaeis guineensis) rhizosphere Cameroon. African Journal of Biotechnology 5:2450-2460.

Goenadi, D., H. Siswanto, and S. Yudho. 2000. Bioactivation of poorly soluble phosphate rocks with a phosphorus-solubilizing fungus. Soil Science Society of American Journal 64:927-932.

Hamaki, T., M. Suzuki, R. Fudou, Y. Jojima, K. Takayuki, T.A. Kajiura, et al. 2005. Isolation of novel bacteria and actinomycetes using soil-extract agar medium. Journal of Bioscience and Bioengineering 99:485-492.

Hamza, S., V. Srinivasan, and R. Dinesh. 2007. Nutrient diagnosis of black pepper (Piper nigrum L.) garden in Kerala and Karnataka. Journal of Spices and Aromatic Crops 16:77-81.

Kang, S.C., P. Pandey, R. Khillon, and D.K. Maheshwari. 2008. Process of phosphate solubilization by Aspergillus sp PS104 in soil amended medium. Journal of Environmental Biology 29:743746.

Levyal, C., and E.J. Janer. 2001. Bioavailability of heavy metals in the mycorrhizosphere. p. 165. In Gobran, G.R., W.W. Wenzel, and E. Lombi (eds.) Trace elements in the rhizosphere. CRC Press, Boca Raton, Florida, USA.

Malakooti, M.J., and M. Nafisi. 1995. Fertilizer utilization in agricultural lands "irrigated and dry land systems". $2^{\text {nd }}$ ed. Tarbiat Modares University Publications, Tehran, Iran.

Mehrvarz, S., and M.R. Chaichi. 2008. Effect of phosphate solubilizing microorganisms and chemical fertilizer on forage and grain quality of barley (Hordeum vulgare L.) American-Eurasian Journal of Agriculture and Environmental Science 3:855-860.

Nopparat, C., M. Jatupornipat, and A. Rittiboon. 2007. Isolation of phosphate solubilizing fungi in soil from Kanchanaburi, Thailand. KMITL Science and Technology Journal 7:137-146.

Ouahmane, L., J. Thioulouse, M. Hafidi, Y. Prin, M. Ducousso, A. Galliana, et al. 2000. Soil functional diversity and P solubilization from rock phosphate after inoculation with native or allochtonous arbuscular mycorrhizal fungi. Forest Ecological Management 241:200-208.
Olsen, S.R., and L.E. Sommers. 1982. Phosphorus. p. 403-430. In A.L. Pageetal (ed.) Methods of soil analysis. Part 2. Agronomy Monograph 9. $2^{\text {nd }}$ ed. ASA and SSSA, Madison, Wisconsin, USA. Parks, E.J., G.J. Olson, F.E. Brinckman, and F. Baldi. 1990. Characterization of high performance liquid chromatography (HPLC) of the solubilization of phosphorus in iron ore by a fungus. Journal of Industrial Microbiology \& Technology 5(23): 183-189.

Pikovskaya, R.I. 1948. Mobilization of phosphorus in soil in connection with vital activity of some microbial species. Microbiologia 17:362-370.

Ponmurugan, P., and C. Gopi. 2006a. Distribution pattern and screening of phosphate solubilizing bacteria isolated from different food and forage crops. Journal of Agronomy 5:600-604.

Ponmurugan, P., and C. Gopi. 2006b. In vitro production of growth regulators and phosphatase activity by phosphate solubilizing bacteria. African Journal of Biotechnology 5:348-350.

Rajankar, P.N., D.H. Tambekar, and S.R. Wate. 2007. Study of phosphate solubilization of fungi and bacteria isolated from saline belt Purna river basin. Research Journal of Agricultural and Biological Sciences 3:701-703.

Rodríguez, H., and R. Fraga. 1999. Phosphate solubilizing bacteria and their role in plant growth promotion. Biotechnological Advances 17:319-339.

Rodríguez, H., R. Fraga, T. Gonzalez, and Y. Bashan. 2006. Genetics of phosphatic solubilization and its potential applications for improving plant growth- promoting bacteria. Plant and Soil 287:15-21.

Schachtman, D.P., R.J. Reid, and S.M. Ayling. 1998. Phosphate uptake by plants: from soil to cell. Plant Physiology 116:447-453.

Seshadri, S., and S. Ignacimuthu. 2002. Variations in heterotrophic and phosphate solubilizing bacteria from Chennai, southeast coast of India. Indian Journal of Marine Sciences 3:69-72.

Sharma, K., G. Dak, A. Agrawal, M. Bhatnagar, and A.R. Sharma. 2007. Effect of phosphate solubilizing bacteria on the germination of Cicer arietinum seeds and seedling growth. Journal of Herbal Medicine and Toxicology 1:61-63.

Singh, C.P., and A. Amberger. 1998. Organic acids and phosphorus solubilization in straw composted with rock phosphate. Bioresource Technology 63:13-16.

Sundara, B., V. Natarajam, and K. Hari. 2002. Influence of phosphorus solubilizing bacteria on the changes in soil available phosphorus and sugarcane and sugar yields. Field Crops Research 77:43-49.

Taalab, A.S., and M.A. Badr. 2007. Phosphorus availability from compacted rock phosphate with nitrogen to sorghum inoculated with phospho-bacterium. Journal of Applied Sciences Research 3:195-201.

Tallapragada, P., and U. Seshachala. 2012. Phosphate-solubilizing microbes and their occurrence in the rhizospheres of Piper betel in Karnataka, India. Turkish Journal of Biology 36:25-35.

Turan, M., N. Ataoglu, and F. Sahin. 2007. Effects of Bacillus FS-3 on growth of tomato (Lycopersicon esculentum L.) plants and availability of phosphorus in soil. Plant and Soil Environment 53:58-64.

Venkateshwarulu, B., A.V. Rao, and P. Raina. 1984. Evaluation of phosphorus solubilization by microorganisms in Aridisols. Journal Indian Society of Soil Science 32:273-277.

Weisburg, W.G., S.M. Barns, D.A. Pelletier, and D.J. Lane. 1991. $16 \mathrm{~S}$ ribosomal DNA amplification for phylogenetic study. Journal of Bacteriology 173:697-707.

Yahya, A., and S.K.A. Azawi. 1998. Occurrence of phosphate solubilizing bacteria in some Iranian soils. 